\title{
Pengaruh Pemberian Fraksi Daun Jambu Biji Merah (Psidium guajava L.) terhadap Tebal Epitel Epididimis Tikus Putih Jantan (Rattus norvegicus)
}

\author{
Ayu Nina Mirania \\ Program Studi Kebidanan, Universitas Katolik Musi Charitas, Indonesia \\ Email: ayu.mirania91@yahoo.com
}

\begin{abstract}
The Effect of Feeding Fractions of Red Guava Leaves (Psidium guajava L.) on the Epithelium Thickness of Epididymis of Male White Rat (Rattus norvegicus). Population growth is increasingly showing alarming problems because it is not balanced with increasing welfare. Therefore we need population control, one of which is the implementation of family planning programs. The implementation of family planning is the responsibility of husband and wife. Plants that can make male antifertility are guava leaves. The purpose of the present research was to analyze the effect of feeding fractions of red guava leaves (Psidium guajava L.) on the epithelium thickness of epididymis of male white rat (Rattus norvegicus). The research was an experimental one, with a postest only control group design. The research sample size was 24 furrow male white mice Sprague Dawley, 60-80 days old. They were divided into 4 treatment groups, each being fed the fractions of $n$-hexane, ethyl acetate, and water-ethanol of guava leaves at a dosage of $80 \mathrm{mg} / \mathrm{mouse} /$ day, compared to CMC $1 \%$ for the control group for 48 days. The research findings showed that there was shrinkage of the epithelium thickness of caput epididymis $(\mathrm{p}=0,037),(\mathrm{p}=0,001)$ in the corpus, and $(\mathrm{p}=0,001)$ in the cauda compared to the control group. It could be a conclusion that the fraction of guava leaves shrinkage the epithelium thickness of caput, corpus and cauda epididymis of male white rat (Rattus novergicus).
\end{abstract}

Keywords: Antifertility, Epithelium thickness of epididymis, Fraction, Guava leaves

\begin{abstract}
Abstrak: Pengaruh Pemberian Fraksi Daun Jambu Biji Merah (Psidium guajava L.) terhadap Tebal Epitel Epididimis Tikus Putih Jantan (Rattus norvegicus). Peningkatan jumlah penduduk semakin menunjukkan permasalahan yang mengkhawatirkan, karena tidak diimbanginya dengan peningkatan kesejahteraan. Untuk itu diperlukan pengendalian jumlah penduduk, salah satunya adalah pelaksanaan program keluarga berencana. Pelaksanaan Pelaksanaan KB merupakan tanggung jawab suami dan istri. Tanaman yang dapat membuat antifertilitas pria adalah daun jambu biji. Penelitian ini bertujuan untuk menganalisa pengaruh Pemberian Fraksi Daun Jambu Biji Merah (P. guajava) terhadap Perubahan Tebal epitel Epididimis Tikus Putih Jantan ( $R$. norvegicus). Penelitian ini merupakan penelitian experimental, dengan rancangan postest only control group design. Besar Sampel penelitian ini sejumlah 24 tikus putih jantan galur Sprague Dawley usia 60-80 hari. Dibagi dalam 4 kelompok perlakuan dengan setiap kelompok diberi fraksi metanol air, etil asetat, dan n-heksan dari daun jambu biji merah dengan dosis $80 \mathrm{mg} / \mathrm{eko} \mathrm{r} / \mathrm{hr}$ dibandingkan dengan CMC $1 \%$ untuk kelompok kontrol selama 48 hari. Hasil penelitian menunjukkan adanya penyusutan tebal epitel caput epididimis $(p=0,037),(p=0,001)$ pada corpus, dan $(p=0,001)$ pada cauda dibanding kelompok kontrol. Dapat disimpulkan bahwa fraksi daun jambu biji merah dapat menyusutkan tebal epitel caput, corpus dan cauda epididimis tikus putih jantan (Rattus novergicus).
\end{abstract}

Kata kunci: Antifertilitas, Tebal epitel epididimis, Fraksinasi, Daun jambu biji merah

\section{PENDAHULUAN}

Kepadatan penduduk di Indonesia merupakan salah satu permasalahan yang dihadapi oleh pemerintah yang sampai sekarang belum dapat diatasi, hal ini disebabkan karena terjadi peningkatan jumlah penduduk setiap tahunnya. Peningkatan jumlah penduduk semakin lama menunjukkan permasalahan yang mengkhawatirkan, karena tidak diimbanginya 
dengan peningkatan kesejahteraan. Oleh karena itu pemerintah menjadikan program keluarga berencana sebagai bagian dari pembangunan nasional (Delfita, 2014). Pelaksanaan Pelaksanaan Keluarga Berencana (KB) merupakan tanggung jawab suami dan istri. Suami memiliki peranan penting dalam mencapai keberhasilan $\mathrm{KB}$, namun sebagian besar program KB memberikan sedikit perhatian pada pemahaman peranan pria dalam penggunaan kontrasepsi yang efektif dan konsisten (Fadilah dan Fajrin, 2015).

Epididimis adalah organ reproduksi pria yang androgen dependent. Epididimis merupakan saluran spermatozoa yang panjang dan berbelit, terbagi atas caput, copus, dan cauda epididimis, melekat erat pada testis dan dipisahkan oleh tunika albugenia. Epitel epididimis memiliki aktivitas penyerapan yang tinggi, sehingga bertanggung jawab terhadap absorbsi bukan hanya cairan yang disekresikan tetapi juga ion dan molekul oeganik yang kecil. Pada cauda epididimis merupakan tempat penyimpanan spermatozoa dalam jumlah besar sekitar $75 \%$. Organ tersebut berperan penting pada proses absorbsi cairan yang berasal dari tubuli seminiferi testis, pematangan, penyimpanan dan penyaluran spermatozoa ke duktus deferens sebelum bergabung dengan plasma semen dan diejakulasikan kedalam saluran reproduksi betina untuk mencapai kehamilan (Wahyuni, dkk., 2012).

Tanaman yang dapat membuat antifertilitas adalah daun jambu biji. Tanaman budi daya jambu biji di Indonesia pada umumnya masih dalam bentuk kultur pekarangan, namun berdasarkan luas areal tanam tahun 1992 dan proyeksi luas panen pada tahun 1993 termasuk urutan ke-12 dari 13 jenis buah-buahan komersial yang dihasilkan di negara kita (Ariani, dkk., 2008).

Jambu (Psidium guajava Linn.), termasuk dalam keluarga Myrtaceae, yang berasal dari Amerika Selatan tropis dan tumbuh liar di Bangladesh, India, Thailand, Brasil, Florida, Hindia Barat, California dan juga di beberapa negara lain. Tindakan farmakologis dan penggunaan obat dari ekstrak air daun jambu biji sebagai obat tradisional meliputi pengobatan berbagai jenis gangguan pencernaan seperti muntah, diare, penghambatan refleks peristaltik, gastroenteritis, aktivitas spasmolitik, disentri, distensi abdomen, perut kembung dan lambung nyeri (Mittal, et al., 2010).

Daun jambu biji merah mengandung zat aktif yang diduga bersifat antifertilitas. Alkaloid dapat mempengaruhi sekresi hormon reproduksi yang diperlukan untuk berlangsungnya proses spermatogenesis, minyak atsiri bekerja tidak pada proses spermatogenesis tetapi pada transportasi sperma, tanin dapat menggumpalkan sperma sehingga menurunkan motilitas dan daya hidup sperma (Wien \& Dian, 2007). Senyawa saponin merupakan berbuih yang yang mempunyai efek negatif pada reproduksi hewan yaitu penghambat pembentukan zigot. Saponin bersifat sitotoksik terutama terhadap sel yang mengalami perkembangan. Sedangkan pada kandungan flavonoid yang berlebih dapat terjadinya penurunan berat epididimis karena adanya kerusakan membran sel epididimis (Delfita, 2014).

Beberapa penelitian pendahuluan dari daun jambu biji merah ( $P$. guajava) menunjukkan adanya antifertilitas. Hal ini sesuai dengan penelitian Arifah (2006) bahwa pemberian dekok daun jambu biji merah ( $P$. guajava) 10 gr menunjukkan penurunan jumlah sel spermatozoa normal yang paling tinggi dalam tubulus seminiferus testis. Penelitian yang dilakukan Delfita (2014) terjadinya penurunan berat epididimis yang disebabkan karena kandungan flavonoid dalam ekstrak teh hitam $1 \mathrm{ml} / 100$ gr/BB sehingga merusak membran sel sehingga sel epididimis menjadi rusak dan proses metabolisme tidak berjalan sebagaimana mestinya. Penelitian yang dilakukan oleh Ashok dan Meenakshi (2004), mengenai pemberian ekstrak kunyit (Curcuma longa L.) terhadap tikus putih menunjukkan terjadinya penurunan berat epididimis. Penurunan berat epididimis ini diduga disebabkan oleh kandungan senyawa flavonoid yang terdapat dalam kunyit yang juga terdapat pada temu putih.

Hasil penelitian dari Fadilah (2015), mengatakan bahwa Biji Saga (Abrus precatorius L.) dengan dosis $75 \mathrm{mg} / \mathrm{kg}$ BB mampu menurunkan bobot organ epididimis, diduga karena adanya kandungan alkaloid yang dapat menurunan kadar testosteron.

Dimana penurunan hormone testosterone ini terjadi dikarenakan FSH menurun dan LH terhambat. Hasil penelitian dari Hartini (2011), alkaloid yang terdapat pada tanaman dapat menekan seksresi dari hormon reproduksi. Adanya alkaloid pada daun jambu biji merah memberikan aktivitas antifertilitas dengan cara menekan sekresi FSH dan LH. Penurunan kadar LH dapat menyebabkan gangguan pada sel leydig, bila kerja sel leydig terhambat maka jumlah testosteron yang dihasilkan akan menurun, sehingga fungsi dari epididimis dapat terganggu (Fadilah, 2015). 
Berdasarkan latar belakang diatas ekstrak daun jambu biji merah (Psidium guajava L.) mempunyai efek antifertilitas, sehingga peneliti mengambil judul "Pengaruh Pemberian Fraksi Daun Jambu Biji Merah (Psidium guajava L.) Terhadap Perubahan Tebal Epitel Epididimis Tikus Putih (Rattus norvegicus)".

\section{METODE}

Penelitian yang dilakukan merupakan penelitian eksperimental di Laboratorium Bagian Biologi Kedokteran FK Unsri, Laboratorium Fakultas MIPA Biologi Unsri, dan Laboratorium Patologi Anatomi Dyatnitalis dari bulan MaretMei. Rancangan penelitian yang digunakan adalah postest only control group design. Hewan uji yang digunakan dalam penelitian ini adalah tikus putih jantan strain Sprague Dawley ${ }^{\circledR}$ usia 60-80 hari sebanyak 24 ekor dengan berat badan 210-220gram yang diperoleh dari Peternakan Bandung.

Perlakuan pada masing-masing kelompok tikus jantan adalah kelompok 1 sebagai kelompok kontrol $\left(\mathrm{K}_{1}\right)$ diberikan CMC $1 \% 2 \mathrm{ml}$ secara oral 1x per hari. Kelompok 2 sebagai kelompok perlakuan 1 (P1) diberikan fraksi metanol daun jambu biji merah ( $P$. guajava) dengan dosis $80 \mathrm{mg} / \mathrm{ekor} / \mathrm{hari}$. Kelompok 3 sebagai kelompok perlakuan 2 (P2) diberikan fraksi etil asetat daun jambu biji merah $(P$. guajava) dengan dosis 80mg/ekor/hari. Kelompok 4 sebagai kelompok perlakuan 3 (P3) diberikan fraksi n-heksan daun jambu biji merah (P. guajava) dengan dosis $80 \mathrm{mg} / \mathrm{ekor} / \mathrm{hari}$.

Proses ekstraksi Sebanyak $2 \mathrm{~kg}$ daun jambu biji dicuci dan dibersihkan, kemudian dikering anginkan selama 2 minggu di dalam ruangan tanpa terkena sinar matahari langsung. Daun yang telah kering kemudian diblender, hingga daun hancur. lalu dilakukan maserasi dengan pelarut metanol sebanyak 1 liter selama 2x24 jam didalam alat ekstraktor kemudian disaring menggunakan kertas saring. Setelah itu dilakukan proses evaporasi yaitu larutan yang telah didiamkan dimasukkan dalam labu, labu evaporasi dipasang pada evaporator dan water bath diisi dengan air sampai penuh kemudian dipanaskan diatur hingga suhu $70^{\circ} \mathrm{C}$ dan dibiarkan sampai larutan metanol memisah dengan zat aktif yang sudah ada dalam labu setelah itu dilanjutkan menggunakan penangas air. Ekstrak daun jambu biji merah ( $P$. guajava) yang didapat kemudian dimasukkan kedalam gelas kaca.

Fraksinasi dilakuakn untuk menarik macam-macam senyawa yang terkandung dalam ekstrak daun jambu biji merah ( $P$. guajava) sesuai dengan kepolarannya, pelarut n-heksan akan melarutkan senyawa nonpolar, pelarut etil asetat akan melarutkan senyawa polar dan pelarut metanol air akan melarutkan senyawa polar.

Proses fraksinasi dilakukan dengan metode FCC (fraksi cair-cair) yakni ekstrak aktif dimasukan kedalam labu pisah dengan menggunakan pelarut-pelarut yang sesuai menjadi 3 fraksi yaitu fraksi n-heksan, fraksi etil asetat, dan fraksi metanol air. Dari ekstrak daun jambu biji merah ( $P$. guajava) yang diperoleh dalam tahap ektraksi ditambahkan dengan aquadest dengan perbandingan 1:1 yaitu sebanyak $150 \mathrm{ml}$ aquades dan ekstraksi 150ml. Selanjutnya ditambahkan pelarut n-heksan sebanyak 1L secara bertahap, setiap kali dimasukan sebanyak $250 \mathrm{ml}$ n-heksan dengan 4 kali pengulangan $(4 \times 250 \mathrm{ml})$.

Fraksi metanol dan n-heksan dipisahkan dengan labu pisah sehingga diperoleh fraksi nheksan lalu diuapkan pada rotary evaporator lalu di hair dryer sampai mengental sehingga didapatkan fraksi berbentuk pasta. Fraksi metanol air dilanjutkan dengan penambahan pelarut etil asetat sebanyak 1L secara bertahap, setiap kali dimasukan sebanyak 250 etil asetat dengan 4 kali pengulangan $(4 \times 250 \mathrm{ml})$ kemudian dipisahkan dengan labu pisah sehingga diperoleh fraksi etil asetat dan fraksi metanol setelah itu dilakukan penguapan pada rotary evapator lalu dihair dryer sampai mengental sehingga didapatkan fraksi berbentuk pasta.

Tahap akhir proses fraksinasi diperoleh tiga fraksi yaitu n-heksan, etil asetat, metanol dalam bentuk pasta. Lalu dilakukan penimbangan fraksi dengan cara timbanglah botol yang kosong sebelum diisi fraksi, selisih berat botol sebelum dan sesudah diberi fraksi adalah berat fraksi yang didapatkan. Ketiga tahap fraksi yang diperoleh diujikan dengan tikus putih jantan $(R$. norvegicus) untuk menentukan fraksi aktif yang mempengaruhi epididimis.

Penelitian ini telah mendapatkan persetujuan etik penelitian (ecthical clearance) dari Komisi Etik Penelitian Rumah Sakit Umum Pusat Mohammad Hoesin dan Fakultas Kedokteran Universitas Sriwijaya No. 028/ kepkrsmhfkunsri/2016. 


\section{HASIL}

Fraksinasi Daun Jambu Biji Merah (P. guajava)

Tabel 1. Hasil fraksinasi Daun Jambu Biji Merah

\begin{tabular}{lrr}
\hline \multicolumn{1}{c}{ Jenis Fraksi } & \multicolumn{1}{c}{$\begin{array}{c}\text { Berat } \\
\text { Fraksi }(\mathbf{g})\end{array}$} & $\begin{array}{r}\text { Persentase } \\
\text { Berat (\%) }\end{array}$ \\
\hline Fraksi n-heksan & 27,00 & 17,56 \\
Fraksi etil asetat & 43,90 & 28,54 \\
Fraksi metanol air & 82,90 & 53,90 \\
\hline Jumlah & $\mathbf{1 4 3 , 7}$ & $\mathbf{1 0 0}$ \\
\hline
\end{tabular}

Dari Tabel 1 dapat dilihat bahwa hasil fraksinasi ekstrak daun jambu biji merah didapat 82,90 gram $(53,9 \%)$ dengan pelarut polar metanol air, mempunyai berat yang lebih besar dibandingkan dengan 43,90gram $(28,54 \%)$ etil asetat sebagai pelarut semi polar dan 27,00 $(17,56 \%)$ n-heksan sebagai pelarut non polar.

\section{Uji Kromatografi Lapis Tipis (KLT)}

Uji Kromatografi Lapis Tipis dilakukan untuk menentukan golongan senyawa yang terdapat dalam daun jambu biji merah $(P$. guajava) yaitu dengan cara fraksi n-heksan, etil asetat, dan metanol \pm 0 ,2gram dimasukkan ke dalam vial kemudian dicampur dengan metanol lalu ditotolkan pada plat silika $\mathrm{F}_{254}$ dikembangkan dengan fase gerak, semprotkan larutan $\mathrm{H}_{2} \mathrm{SO}_{4}$. Letakkan diatas hot plate kemudian amati bercak warna yang muncul.

Tabel 2. Hasil Uji KLT Fraksi Daun Jambu Biji Merah

\begin{tabular}{|c|c|c|}
\hline Bahan Uji & $\begin{array}{l}\text { Warna } \\
\text { Bercak }\end{array}$ & $\begin{array}{c}\text { Senyawa } \\
\text { Golongan }\end{array}$ \\
\hline Fraksi N-Heksan & Ungu & Steroid \\
\hline Fraksi Etil Asetat & Kuning & Alkaloid \\
\hline Fraksi Metanol Air & Merah Bata & Flavonoid \\
\hline
\end{tabular}

Berdasarkan uji kualitatif kromatografi diatas menunjukkan bahwa fraksi daun jambu biji merah ( $P$. guajava) terdapat komponen pada fraksi N-Heksan terdapat warna bercak ungu dengan senyawa golongan steroid, pada fraksi Etil Asetat terdapat bercak warna kuning dengan senyawa golongan Alkaloid, dan fraksi Metanol air terdapat warna bercak merah bata dengan senyawa golongan flavonoid.

\section{Karakteristik Sampel}

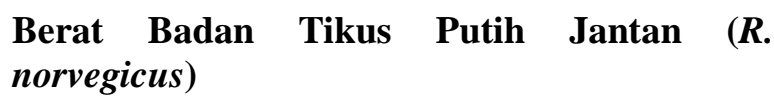

Hasil karakteristik berat badan tikus putih jantan ( $R$. norvegicus) dapat dilihat pada tabel dibawah ini:

\begin{tabular}{|c|c|c|c|c|c|}
\hline Kel. & & $\begin{array}{c}\text { Berat } \\
\text { badan } \\
\text { sebelum } \\
\text { (gram) } \\
\overline{\mathbf{x}}\end{array}$ & 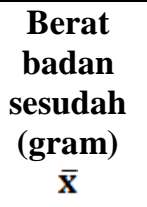 & $\begin{array}{l}\Delta \text { Berat } \\
\text { Badan } \\
\text { (gram) }\end{array}$ & $\%$ \\
\hline K0 & 6 & 216,33 & 283,33 & 67,00 & 31,10 \\
\hline P1 & 6 & 214,17 & 275,00 & 60,83 & 28,32 \\
\hline P2 & 6 & 215,00 & 278,33 & 63,33 & 29,41 \\
\hline P3 & 6 & 218,00 & 258,33 & 40,33 & 18,49 \\
\hline
\end{tabular}

Dari hasil karakteristik sampel berat badan tikus pada Tabel 3 diatas, didapat bahwa selisih berat badan tikus pada setiap kelompok perlakuan mengalami kenaikan berat berat badan setelah diberi fraksi daun jambu biji merah selama 48 hari.

\section{Uji Homogenitas Berat Badan Tikus Putih Jantan}

Uji homogenitas dilakukan sebagai syarat untuk melakukan uji Anova. Hasil uji homogenitas berat badan tikus putih jantan dapat dilihat pada tabel dibawah ini:

Tabel 4. Uji Homogenitas Berat Badan Tikus Putih Jantan

\begin{tabular}{clccc}
\hline Kel & Perlakuan & n & $\begin{array}{c}\text { Berat badan } \\
\text { tikus (gram) } \\
\overline{\mathbf{x}} \pm \text { SD }\end{array}$ & $\begin{array}{c}\boldsymbol{p} \text { - } \\
\text { value }\end{array}$ \\
\hline K0 & CMC 1\% 2 ml & 6 & $216,33 \pm 3,83$ & \\
P1 & $\begin{array}{l}\text { Fraksi metanol } \\
\text { air 80mg/ekor/hr }\end{array}$ & 6 & $214,17 \pm 4,91$ & 0,709 \\
P2 & $\begin{array}{l}\text { Fraksi etil asetat } \\
\text { 80mg/ekor/hr }\end{array}$ & 6 & $215,00 \pm 4,47$ & \\
P3 & $\begin{array}{l}\text { Fraksi n-heksan } \\
\text { 80mg/ekor/hr }\end{array}$ & 6 & $218,00 \pm 4,00$ & \\
\hline
\end{tabular}

Dari hasil uji homogenitas berat badan tikus pada Tabel 4 diatas, dapat dilihat bahwa nilai $p=0,709(p>0,05)$ yang berarti berat badan tikus pada setiap kelompok perlakuan homogen sehingga persyaratan penelitian eksperimental terpenuhi dan penelitian dapat dilanjutkan. 
Pengaruh Fraksi Daun Jambu Biji Merah terhadap Tebal Epitel Caput Epididimis

Pengaruh fraksi daun jambu biji merah terhadap tebal epitel caput epididimis tikus putih jantan setelah perlakuan selama 48 hari terhadap 24 tikus terlihat adanya penyusutan tebal epitel caput epididimis, untuk melihat perbandingan rata-rata tebal epitel caput epididimis antar kelompok dilakukan uji Anova dan dilanjutkan dengan uji lanjut Duncan didapat hasil sebagai berikut:

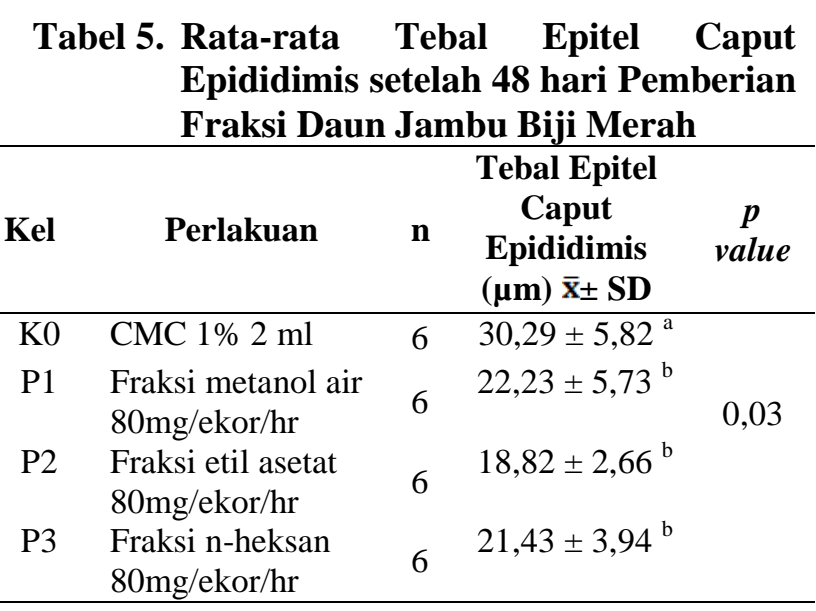

Berdasarkan tabel 5 terlihat bahwa terjadi penurunan tebal epitel caput epididimis pada kelompok tikus yang diberi perlakuan. Hasil uji Anova didapatkan $p$-value $=0,03(p<0,05)$, yang berarti bahwa fraksi daun jambu biji merah memiliki pengaruh terhadap tebal epitel caput epididimis.

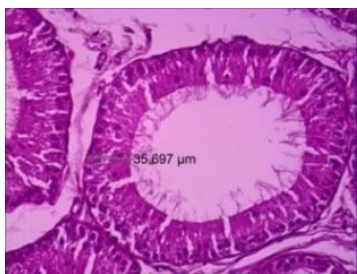

(A)

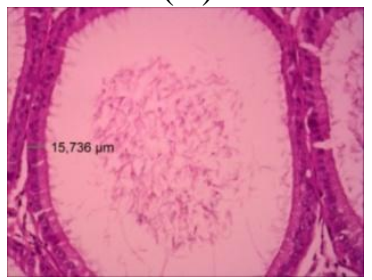

(C)

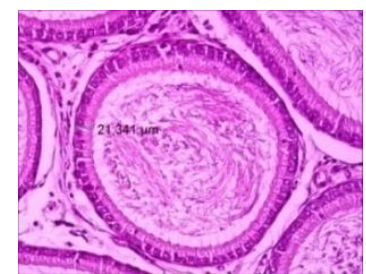

(B)

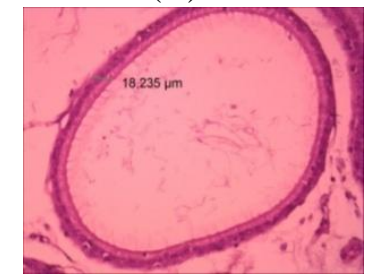

(D)
Gambar 1. Penampang histologis caput epididimis dengan melintang; (A) tebal epitel caput epididimis kontrol 35,697 $\mu \mathrm{m}$, (B) setelah diberi fraksi metanol air $21,341 \mu \mathrm{m}$, (C) fraksi etil asetat $15,736 \mu \mathrm{m}$, , (D) fraksi n-heksan 18,235 $\mu$ m (Perbesaran $400 \mathrm{X}$ ).
Pengaruh Fraksi Daun Jambu Biji Merah terhadap Tebal Epitel Corpus Epididimis

Pengaruh fraksi daun jambu biji merah terhadap tebal epitel corpus epididimis tikus putih jantan setelah perlakuan selama 48 hari terhadap 24 tikus terlihat adanya penyusutan tebal epitel corpus epididimis, untuk melihat perbandingan rata-rata tebal epitel caput epididimis antar kelompok dilakukan uji Anova sebagai berikut:

Tabel 6. Rata-rata Tebal Epitel Corpus Epididimis setelah 48 hari Pemberian Fraksi Daun Jambu Biji Merah

\begin{tabular}{clccc}
\hline Kel & \multicolumn{1}{c}{ Perlakuan } & n & $\begin{array}{c}\text { Tebal Epitel } \\
\text { Corpus } \\
\text { Epididimis } \\
(\boldsymbol{\mu m}) \overline{\mathbf{x}} \pm \text { SD }\end{array}$ & $\begin{array}{c}\boldsymbol{p} \\
\text { value }\end{array}$ \\
\hline K0 & CMC 1\% 2 ml & 6 & $24,42 \pm 3,64^{\mathrm{a}}$ & \\
P1 & $\begin{array}{l}\text { Fraksi metanol air } \\
\text { 80mg/ekor/hr }\end{array}$ & 6 & $19,58 \pm 1,35^{\mathrm{b}}$ & 0,001 \\
P2 & $\begin{array}{l}\text { Fraksi etil asetat } \\
\text { 80mg/ekor/hr }\end{array}$ & 6 & $18,83 \pm 2,46^{\mathrm{b}}$ & \\
P3 & $\begin{array}{l}\text { Fraksi n-heksan } \\
\text { 80mg/ekor/hr }\end{array}$ & 6 & $17,02 \pm 2,87^{\mathrm{b}}$ & \\
\hline
\end{tabular}

Berdasarkan tabel 6 terlihat bahwa terjadi penurunan tebal epitel corpus epididimis pada kelompok tikus yang diberi perlakuan. Hasil uji Anova didapatkan $p$-value $=0,037(p<0,05)$, yang berarti bahwa fraksi daun jambu biji merah memiliki pengaruh terhadap tebal epitel corpus epididimis.

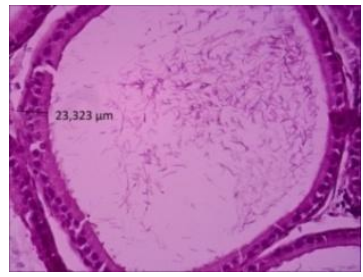

(A)

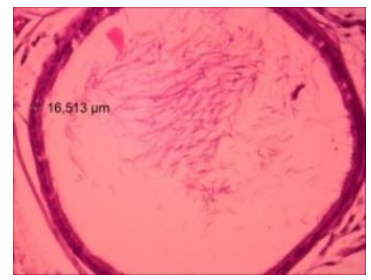

(C)

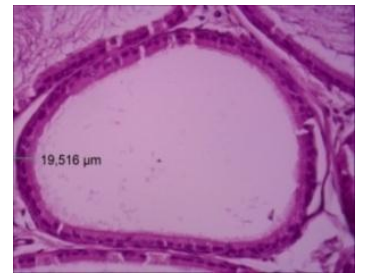

(B)

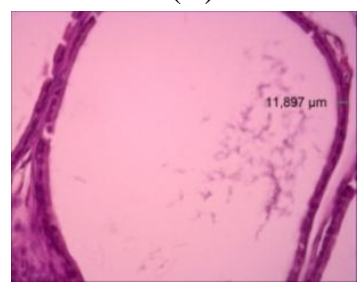

(D)
Gambar 2. Penampang histologis corpus epididimis pemotongan melintang; (A) tebal epitel corpus epididimis kontrol $23,323 \mu \mathrm{m}$, (B) setelah diberi fraksi metanol air $19,516 \mu \mathrm{m}$, (C) fraksi etil asetat $16,513 \mu \mathrm{m}$, (D) fraksi n-heksan 11,897 $\mu \mathrm{m}$ (Perbesaran $400 \mathrm{X}$ ). 
Pengaruh Fraksi Daun Jambu Biji Merah Terhadap Tebal Epitel Cauda Epididimis

Pengaruh fraksi daun jambu biji merah terhadap tebal epitel cauda epididimis tikus putih jantan setelah perlakuan selama 48 hari terhadap 24 tikus terlihat adanya penyusutan tebal epitel cauda epididimis, untuk melihat perbandingan rata-rata tebal epitel caput epididimis antar kelompok dilakukan uji Anova didapat hasil sebagai berikut:

\begin{tabular}{|c|c|c|c|c|}
\hline Tabel & \multicolumn{4}{|c|}{$\begin{array}{l}\text { Rata-rata Tebal Epitel Cauda } \\
\text { Epididimis setelah } 48 \text { hari Pemberian } \\
\text { Fraksi Daun Jambu Biji Merah }\end{array}$} \\
\hline & & & Tebal Epitel & \\
\hline Kel & Perlakuan & $\mathbf{n}$ & $\begin{array}{l}\text { Cauda } \\
\text { Epididimis } \\
(\mu \mathrm{m}) \overline{\mathrm{x}} \pm \mathrm{SD}\end{array}$ & $\begin{array}{c}p \\
\text { value }\end{array}$ \\
\hline K0 & CMC $1 \% 2 \mathrm{ml}$ & 6 & $21,98 \pm 4,52$ & \\
\hline P1 & $\begin{array}{l}\text { Fraksi metanol } \\
\text { air } \\
80 \mathrm{mg} / \mathrm{ekor} / \mathrm{hr}\end{array}$ & 6 & $16,04 \pm 1,46$ & \\
\hline $\mathrm{P} 2$ & $\begin{array}{l}\text { Fraksi etil } \\
\text { asetat } \\
80 \mathrm{mg} / \mathrm{ekor} / \mathrm{hr}\end{array}$ & 6 & $15,14 \pm 2,97$ & 0,001 \\
\hline P3 & $\begin{array}{l}\text { Fraksi n-heksan } \\
80 \mathrm{mg} / \mathrm{ekor} / \mathrm{hr}\end{array}$ & 6 & $13,94 \pm 1,42$ & \\
\hline
\end{tabular}

Berdasarkan hasil analisis uji one way anova didapatkan hasil bahwa ada perbedaan rerata tebal epitel cauda epididimis antar kelompok perlakuan $p$-value $=0,001 \quad(p<0,05)$, yang berarti bahwa ada perbedaan bermakna dari pemberian fraksi daun jambu biji merah sehingga dapat disimpulkan bahwa fraksi daun jambu biji merah memiliki pengaruh terhadap tebal epitel cauda epididimis.

Berdasarkan hasil di atas, maka dilanjutkan uji post hoc test games howel karena pada varian data tidak homogen, analisis ini bertujuan untuk melihat perbedaan rerata tebal epitel masing-masing kelompok perlakuan.

\begin{tabular}{|c|c|c|c|c|}
\hline & $\begin{array}{c}\text { CMC 1\% } \\
2 \mathrm{ml}\end{array}$ & $\begin{array}{c}\text { Fraksi } \\
\text { metanol air } \\
\text { 80mg/ekor/ } \\
\text { hr }\end{array}$ & $\begin{array}{c}\text { Fraksi etil } \\
\text { asetat } \\
\text { 80mg/ekor/ } \\
\text { hr }\end{array}$ & $\begin{array}{c}\text { Fraksi n- } \\
\text { heksan } \\
\text { 80mg/ekor/ } \\
\text { hr }\end{array}$ \\
\hline $\mathrm{MC} 1 \% 2 \mathrm{ml}$ & & 0,080 & 0,054 & 0,023 \\
\hline $\begin{array}{l}\text { Fraksi } \\
\text { hetanol air } \\
\text { 0mg/ekor/hr }\end{array}$ & 0,080 & & 0,906 & 0,116 \\
\hline $\begin{array}{l}\text { raksi etil } \\
\text { setat } \\
\text { 0mg/ekor/hr }\end{array}$ & 0,054 & 0,906 & & 0,810 \\
\hline $\begin{array}{l}\text { raksi n- } \\
\text { eksan } \\
\text { Omg/ekor/hr }\end{array}$ & 0,023 & 0,116 & 0,810 & \\
\hline
\end{tabular}

Hasil analisis lebih lanjut menggunakan Multiple Comparations (Post Hoc Test) Games Howell menunjukkan bahwa terjadi penurunan rata-rata pada tebal epitel cauda epididimis. Pada kelompok perlakuan K0 dibandingkan P1 dan P2 tidak terdapat perbedaan bermakna, namun pada kelompok K0 dan P3 terlihat ada perbedaan bermakna. Untuk kelompok antara P1, P2, dan P3 tidak ada perbedaan bermakna tetapi pada kelompok P3 lebih efektif dalam menurunkan tebal epitel cauda epididimis.

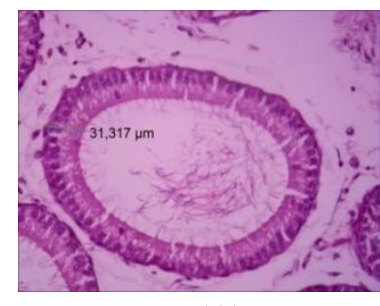

(A)

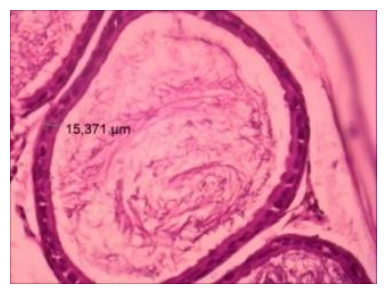

(C)

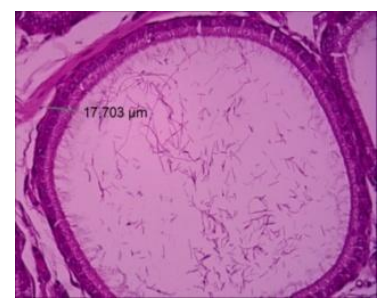

(B)

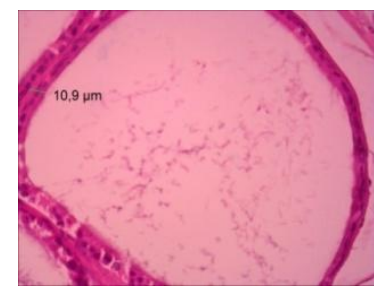

(D)
Gambar 3. Penampang histologis cauda epididimis pemotongan melintang; (A) tebal epitel cauda epididimis kontrol $31,317 \mu \mathrm{m}$, (B) setelah diberi fraksi metanol air $17,703 \mu \mathrm{m}$, (C) fraksi etil asetat $15,371 \mu \mathrm{m}$, (D) fraksi n-heksan 10,9 $\mu \mathrm{m}$ (Perbesaran $400 \mathrm{X}$ ).

\section{PEMBAHASAN}

\section{Tebal Epitel Caput Epididimis}

Hasil pada penelitian menunjukkan bahwa terjadi penurunan tebal epitel caput epididimis. Penurunan mulai terlihat berbeda bermakna terjadi pada kelompok K0 dibandingkan dengan P1, P2, dan P3. Untuk kelompok P1, P2, dan P3 terlihat tidak berbeda bermakna namun pada kelompok perlakuan P2 lebih membuat penyusutan tebal epitel caput epididimis.

Hal ini menunjukkan bahwa pemberian fraksi etil asetat lebih menyebabkan menyusutnya ketebalan epitel caput. Diduga dari kandungan senyawa alkaloid yang ada pada fraksi etil asetat dapat mengganggu membran sel. Terganggunya membran sel diakibatkan transfer zat makanan 
yang dibutuhkan dalam regenerasi sel terganggu sehingga proses pertumbuhan atau perkembangan dari sel epididimispun terhambat dan menyusutkan tebal epitel.

Hasil penelitian ini sejalan dengan penelitian Wahyuni (2012), bahwa apabila sel sertoli terganggu akan menyebabkan penurunan sekresi ABP, apabila sekresi ABP terganggu maka ABP tidak dapat mengikat testosteron testosteron yang diperlukan oleh epididimis. Terhambatnya testosteron ini menyebabkan menurunnya aksi kerja enzim $5 \alpha$ - reduktase sehingga menurunkan hormon androgen khususnya $5 \alpha$-dehidrotestosteron. Selanjutnya penurunan $5 \alpha$-dehidrotestosteron menyebabkan terganggunya sekresi bahan-bahan yang dibutuhkan untuk kontraksi otot-otot polos epididimis dan untuk reabsorbsi cairan oleh sel epitel epididimis terutama sel principal yang berfungsi sebagai transport dan sintesis protein (Robaire, 2006). Regenerasi sel-sel sangat membutuhkan protein dalam prosesnya termasuk regenerasi sel-sel yang berada di dalam epididimis. Jika sel-sel yang ada dalam epididimis kekurangan protein, maka proses regenerasi sel akan terhambat, dan mengakibatkan degenerasi sel yaitu kemunduran atau perubahan morfologi pada sel yang bila dalam keadaan lama dapat menyebabkan nekrosis (kematian) sel (Widyati, 2012).

Menurut Fajria (2011), yang menyatakan bahwa alkaloid dan flavanoid pada estrak daun pandan wangi menyebabkan gangguan pada membran sel dengan cara merubah komponen penyusun membran dan akibat perubahan tersebut mengakibatkan proses fisiologis pada membran terganggu, yakni gangguan pada transportasi nutrisi sel dan proses pembentukan energi terganggu serta menyebabkan kematian pada sel. Dan menurut Wien \& Dian (2007), bahwa penyusutan tebal epitel tersebut diduga karena adanya kandungan senyawa steroid, flavonoid, dan alkaloid pada daun jambu biji merah. Alkaloid pada daun jambu biji merah diduga bertanggung jawab atas aktivitas antifertilitas dan berpengaruh terhadap kadar hormon testosteron serta organ reproduksi.

\section{Tebal Epitel Corpus Epididimis}

Hasil analisis lebih lanjut menggunakan Multiple Comparisons (Posthoc Test) Duncan Test menunjukkan bahwa terjadi penurunan tebal epitel corpus epididimis. Penurunan mulai terlihat berbeda bermakna terjadi pada kelompok K0 dibandingkan dengan P1, P2, dan P3. Untuk kelompok P1, P2, dan P3 terlihat tidak berbeda bermakna namun pada kelompok P3 lebih menyebabkan penyusutan tebal epitel corpus epididimis.

Hal ini menunjukkan bahwa pemberian fraksi n-heksan lebih berpengaruh terhadap menyusutnya tebal epitel corpus. Diduga dari kandungan senyawa beta-sitosterol yang ada pada fraksi n-heksan dapat meningkatkan testosteron. senyawa beta-sitosterol memiliki struktur kimia yang sama dengan hormon steroid (testosteron) didalam darah, dan membuat hormon testosteron didalam darah meningkat. Peningkatan ini membuat umpan balik negatif sehingga sekresi FSH menurun dan LH terhambat yang akibatnya menyebabkan atropi pada sel epididimis.

Menurut Cholifah (2014), apabila sekresi LH terhambat maka menyebabkan pertumbuhan dan jumlah sel Leydig berkurang sehingga sekresi hormon testosteron juga ikut berkurang. Hal ini dikarenakan sel Leydig merupakan tempat terjadinya proses steroidogenesis yang menghasilkan testosteron, jika jumlah atau fungsinya berkurang maka produksinya pun akan berkurang. Setelah disekresikan, testosteron tersebut selanjutnya diikat oleh ABP yang disekresikan oleh sel sertoli. FSH berperan merangsang sel sertoli untuk mensekresikan ABP (androgen binding protein) yang berfungsi mengikat testosteron. Jika FSH terganggu maka Sel sertoli juga terganggu sehingga menyebabkan penurunan sekresi ABP. Hal ini berakibat ABP tidak dapat berikatan dengan testosteron, sehingga menyebabkan transport testosteron ke epididimis terhambat dan menyebabkan atropinya sel-sel epitel.

Sedangkan kemungkinan lain terjadinya penyusutan tebal epitel epididimis disebabkan karena terjadinya kerusakan membran sel epididimis akibat kandungan/dosis flavonoid yang berlebih yang bertindak sebagai antioksidan membentuk Reactive Oxygen Species (ROS) yang baru dan akan merusak membran sel sehingga sel epididimis menjadi rusak dan proses metabolisme tidak berjalan sebagaimana mestinya. Akibatnya sel/organ menjadi kecil yang ditandai dengan berkurangnya berat dan menyebabkan kematian dari sel/organ. Peningkatan kadar ROS akan menghasilkan stress oksidatif akibat kadar ROS melampaui batas pertahanan antioksidan tubuh sehingga akan menyebabkan kerusakan sel, jaringan dan organ (Sikka, 2004).

Hasil penelitian ini sejalan dengan penelitian Lenny (2006), menyatakan bahwa senyawa beta-sitosterol yang ada pada daun jambu biji merah memiliki struktur kimia yang 
sama dengan hormon steroid (testosteron), senyawa ini memiliki sifat anti-androgenik yang dapat menghambat testosteron berikatan dengan ABP. Adanya persamaan struktur kimia antara beta-sitosterol dengan hormon testosteron tersebut mengakibatkan terjadi kompetisi dalam jalur biosintesis hormon seks. Dan Delfita (2014) bahwa kandungan kimia flavonoid yang berlebih dapat mengakibatkan terjadinya kerusakan membran sel epididimis.

\section{Tebal Epitel Cuada Epididimis}

Hasil analisis lebih lanjut menggunakan Multiple Comparations (Post Hoc Test) Games Howell menunjukkan bahwa terjadi penyusutan tebal epitel cauda epididimis yang lebih efektif pada kelompok perlakuan n-heksan.

Hal ini menunjukkan bahwa pemberian fraksi n-heksan lebih berpengaruh terhadap menyusutnya ketebalan epitel cauda. Terjadinya penyusutan tebal epitel cauda diduga dari kandungan senyawa steroid yang ada pada fraksi n-heksan yang berikatan dengan reseptor estrogen, sehingga dapat menurunkan kadar testosteron dan berpengaruh pada morfologi sel epitel.

Hasil penelitian ini sejalan dengan penelitian Cholifah (2014), menyatakan bahwa kandungan senyawa steroid merupakan senyawa yang bersifat anti androgenik yang dapat menghambat testosteron. Apabila testosteron terhambat maka terjadi perubahan pada sel epididimis karena.

Terhambatnya testoteron berpengaruh pada tebal epitel epididimis. Testoteron berperan mengatur morfologi sel epitel epididimis (Cholifah, 2014). Apabila testoteron terhambat mencapai epididimis maka morfologi sel epitel epididimis mengalami penurunan dan bila semakin lama akan terjadi degenerasi sel epitel epididimis. Dengan terhambatnya testoteron maka fungsi sel halo pada epididimis sebagai pertahanan akan terganggu akibatnya bahan bio aktif yang bersifat toksik seperti: Alkaloid, flavonoid dan steroid dapat berpengaruh terhadap tebal epitel epididimis, sehingga terjadi degenerasi pada sel epitel epididimis yang berdampak pada penurunan ketebalan epitel epididimis.

Begitupula hasil penelitian Cholifah (2014), menyatakan bahwa terjadinya penyusutan tebal epitel epididimis pada ekstrak pare (Momordica charantia, L) dengan dosis $25 \mathrm{mg} / 100 \mathrm{~g}$ BB dan $50 \mathrm{mg} / 100 \mathrm{~g}$ BB karena adanya kandungan senyawa steroid yang menghambat testosteron. testosteron yang mengatur morfologi sel epitel epididimis, sehingga apabila testosteron menurun maka morfologi sel epitel epididimis mengalami penyusutan yang semakin lama dapat menyebabkan terjadinya degenerasi sel epitel epididimis.

\section{SIMPULAN}

Berdasarkan hasil penilitian mengenai pengaruh pemberian fraksi daun jambu biji merah ( $P$. guajava) terhadap tebal epitel caput, corpus, dan cauda epididimis tikus putih jantan ( $R$. norvegicus) selama 48 hari secara oral maka dapat disimpulkan bahwa fraksi daun jambu biji merah ( $P$. guajava) berpengaruh terhadap penyusutan tebal epitel caput, corpus, dan cauda epididimis putih jantan ( $R$. norvegicus)

\section{DAFTAR PUSTAKA}

Ariani, Sri Retno Dwi, Endang S., Elfi S, Setiyani. (2008). Uji Aktivitas Ekstrak Metanol Daun Jambu Biji (Psidium guajava L.) sebagai Antifertilitas Kontrasepsi pada Tikus Putih (Rattus norvegicus). Indo. J. Chem. 8 (2), 264-270.

Arifah, K. (2006). Uji efektivitas dekok daun jambu biji (Psidium guajava l.) terhadap sel spermatozoa normal dan abnormal dalam tubulus seminiferus testis tikus putih jantan. (Tesis, Universitas Muhammadiyah Malang). Malang.

Ashok, P., B. Meenakshi. (2004). Contraceptive Effect Of Curcuma longa (L.) in Male Albino Rat. Asian J Androl.
Cholifah, S., Arsyad, Salni. (2014). Pengaruh Ekstrak Pare (Momordica Charantia L.) Terhadap Struktur Histologi Testis dan Epididimis Tikus Jantan (Rattus norvegicus) Spraque Dawley. Jurnal Kesehatan Politeknik Kesehatan Makasar, Th 46 Nomor 2.

Delfita, Rina. (2014). Potensi Antifertilitas Ekstrak Teh Hitam Pada Mencit (Mus Musculus L.) Jantan. Jurnal Sainstek, Vol. VI No. 2: 181-188.

Fadilah, Muslichah, S., dan Fajrin, F., A. (2015). Pengaruh Ekstrak Metanol, Fraksi nHeksan, dan Fraksi Metanol Biji Saga (Abrus precatorius Linn.) terhadap Kadar 
Testosteron dan Bobot Organ Reproduksi Tikus Jantan. (Artikel Ilmiah Hasil Penellitian Mahasiswa, Fakultas Farmasi Universitas Jember). Jember.

Fajria, L. (2011). Pengaruh Pemberian Ekstrak Daun Pandan Wangi (Pandanus amarillyfolus Roxb.) Terhadap Berat Testis dan Diameter Tubulus Mencit (Mus musculus). News Jurnal Keperawatan (7), No.2, hal:161-169.

Hartini. (2011). Pengaruh Dekok Daun Jambu Biji Merah (Psidium guajava.L) Terhadap Jumlah Kecepatan Dan Morfologi Spermatozoa Tikus Putih Jantan (Rattus norvegicus). (Tesis. Program Studi Ilmu Biomedik UNAND).

Lenny, S. (2006). Senyawa Flanonoida, Fenil Flavonoida, dan Alkaloida. (Karya Ilmiah, Universitas Sumatera Utara). Medan.

Mittal, Payal., Vikas G, Gurpreet. (2010). Phytochemistry And Pharmacological Activities Of Psidium Guajava: A Review. Mittal et al. IJPSR, Vol. 1 (9): 9-19.

Robaire, B., Hinton, B.T., and Claire, Marie O.C. (2006). Knobil and Neill's Physiology of
Reproduction, Third Edition: The Epididymis. Raven Press, New York p. 999-1080.

Sikka, S., C. (2004). Relative Impact of Oxidative Stress on Male Reproductive Function. Curr Med Chem.Vol 8:851-862.

Wahyuni, S., Srihadi, A., Muhammad, A., Tuty, L. Y. (2012). Histologi dan Histomorfometri Testis dan Epididimis Muncak (Muntiaws Muncak) Pada Periode Ranggah Keras. Jurnal Veteriner, Vol.13 No.3:211-219.

Widyati, R., M. (2012). Pengaruh ekstrak Daun Jati Belanda (Gauzuma ulmifolia Lamk) Terhadap Berat, Berat testis dan jumlah Sperma Mencit (Mus musculus L.) Galus Swiss Webster. Digital Repository. Universitas Pendidikan Indonesia. Bandung.

Wien.W, Dian S. (2007). Informasi Tanaman Obat Untuk Kontrasepsi Tradisional (http://www.kalbefrafma/file/10/Informasi TanamanObatUntukKontrasepsi120.pdf., diakses tanggal 12 November 2016). 